Wentia 15 (1966) 83-108

\title{
VEGETATION AND HABITAT OF THE SALT MARSHES AND BEAGH PLAINS IN THE SOUTH-WESTERN PART OF THE NETHERLANDS
}

\author{
W. G. BEEFTINK \\ (Hydrobiological Institute, division Delta-Research, Yerseke, the Netherlands) \\ (Communication nr. 34) \\ (received July 15th, 1965)
}

\section{CONTENTS}

1. IntRodUction . . . . . . . . . . . . . . . 83

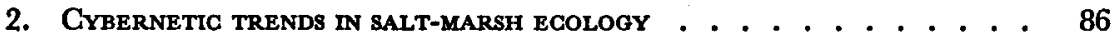

3. HYDROGRAPHY . . . . . . . . . . . . . . 88

4. Genesis of salt marshes. . . . . . . . . . . . . . . . 90

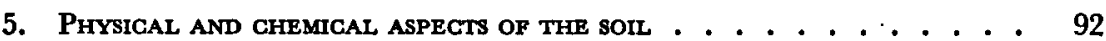

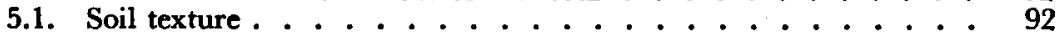

5.2. Carbonates . . . . . . . . . . . . . . . 92

5.3. Soil moisture, ground-water movements, and aeration. . . . . . 93

5.4. Salinity. . . . . . . . . . . . . 95

5.5. Supply of organic matter $\ldots \ldots \ldots \ldots \ldots$

6. The vegetation . . . . . . . . . . . . . . 97

6.1. Zonation and succession $\ldots \ldots \ldots \ldots$

6.2. Plant communities on mud flats $\ldots \ldots \ldots 100$

6.3. Plant communities on salt marshes and beach prains . . . . . 102

6.4. Plant communities on tidal drift . . . ......... 103

7. EpLLOGUR . . . . . . . . . . . . . . . 104

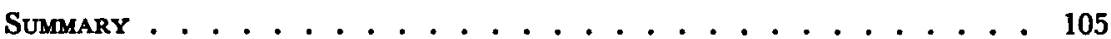

ACKNOWLEDGEMENT. . . . . . . . . . . . . . 105

REFERENGES . . . . . . . . . . . . . 109

\section{INTRODUCTION}

Geographically the coasts of the Netherlands can be devided into three parts: (1) The coastal area (Wadden Area) of the Shallows and the Frisian Islands in the north, (2) the straight coast-line of beaches and dunes between Den Helder and Hook of Holland, in which no salt marshes occur and (3) the south-western part of the country characterized by estuarine formations.

The Wadden Area consists of vast sand and mud flats, separated by creeks and channels of different dimensions. In the direction of the coast these flats mostly change into salt marshes. Seawards, in the direction of the Frisian Islands, they change mainly into beach plains. The vegetation of the mud flats and salt marshes was studied by Feekes $(1934,1941)$, De Vries $(1935,1940)$, Harmsen (1936) and Den HaRTog (1958). The beach plains of the Frisian Islands and their 
adjacent dunes and salt marshes show a very differentiated vegetation with many rare species combinations. This vegetation was described by Braun-Blanguet and De Leeuw (1936), Brouwer et al. (1950), but especially by WeSTHOFF (1941, 1943, 1947, 1951a and b, 1954) and Westhoff and BrouWer (1951).

In the same way as the Wadden Area in the north, the south-western part of the country was formed by transgressions of the sea. Together with the adjacent coastal regions the latter consisted formerly of a lagoon-like area isolated from the sea by coastal barriers. These dune ridges were locally intersected by the river-mouths of Rhine, Meuse and Scheldt. During periods of increased marine ingression into the coastal area inroads of the sea shifted the transition zone between salt and fresh water more and more inland. During these periods mainly marine sediments were deposited, in the periods in between peat formation took place. After the Roman period the south-western Netherlands were eroded from several inlets. Deposition of sand and silty clay took place along deep erosion channels, while mainly clay was deposited in the preserved peat areas (Pons et al., 1963; VAN StraAten, 1963). The estuarine character of the south-western Netherlands is also shown in the relation between fluvial and marine material transported by tidal streams in the river-mouths (TERWINDT et al., 1963).

After this time man began to play a part in consolidating the land remnants by embankment of salt marshes. In the course of time starting from the 12 th century about a thousand polders were constructed in the area leading to the present situation as shown in Fig. 1. The flood disaster of the first of February 1963, when large parts of the area were flooded and hundreds of people lost their lifes, led to the decision of the Government to shut off the waters between the islands except the Nieuwe Waterweg (Rotterdam Waterway) and the Western Scheldt. This work is being executed now and some dams are already finished (Fig. 1).

In the SW Netherlands the maritime vegetation sensu TANSLEY (1949) includes the plant communities occupying the following habitats :

(1) The sand and mud flats, together with the salt and brackish marshes of the intertidal zone where these are protected from the more violent actions of tide-runs and waves.

(2) The coastal beach plains where these are protected by foredunes and other coastal barriers.

(3) The uppermost zone of the sea shore on exposed coasts, barely reached by the spring tides.

(4) Coastal sand dunes.

(5) Salt and brackish, mostly muddy grass-lands on the landside of the dikes, bordering old creeks and pools of former dike-bursts, and situated in localities with seepage of salt water, in excavated fields behind the sea-dikes, etc. 


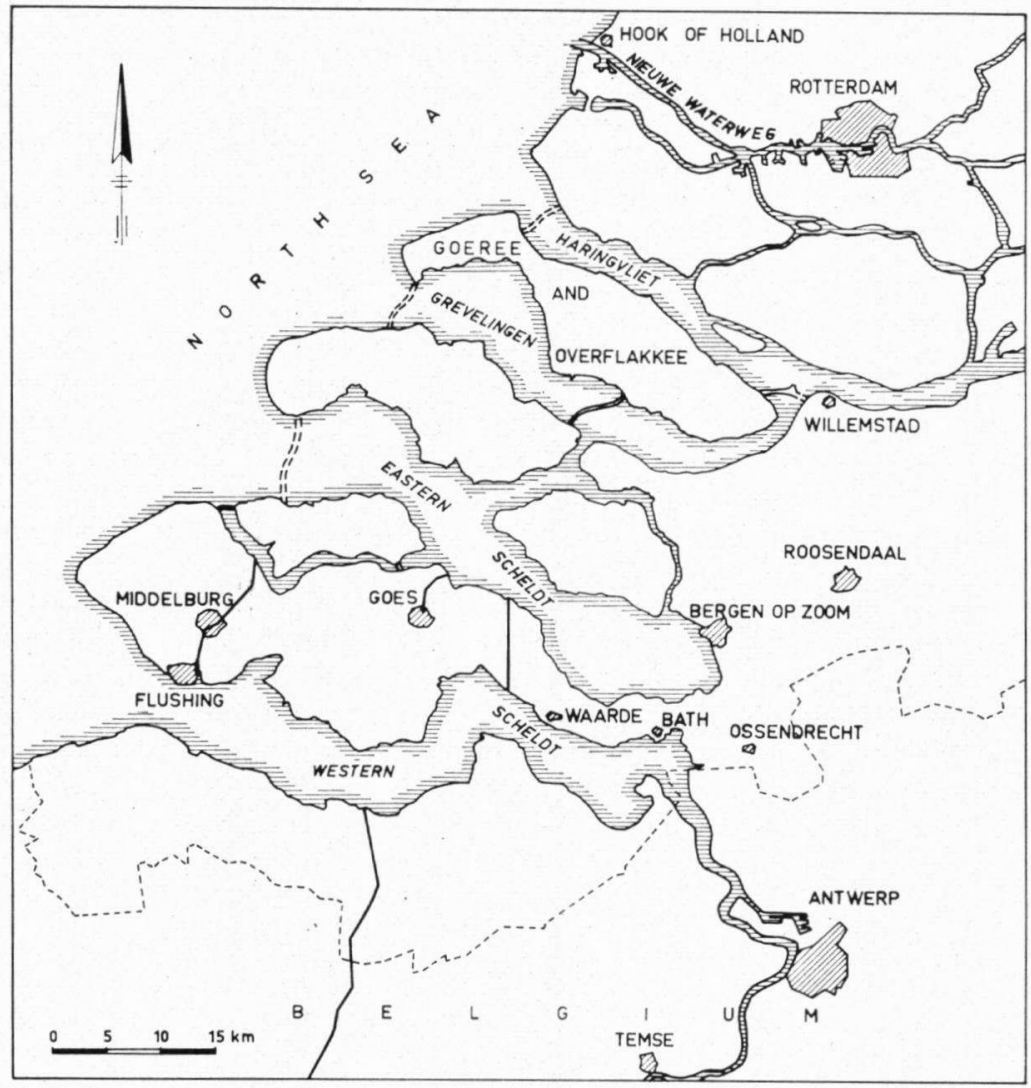

Fig. 1. Topography of the area of investigation

The coastal sand dunes will not be treated in the present article. Of the other habitats formerly salt marshes and beach plains attracted most attention. Fifteen years ago numerous localities stood at the ecologist's disposal. Nowadays, however, in consequence of the flood disaster in 1953, several salt marshes have already been embanked, excavated or otherwise disturbed. Fortunately, it was possible to investigate most of these before they were destroyed. In estuaries generally mud flats ("slikken") and salt marshes ("schorren") in the proper sense of the word are more numerous than beach plains because more silt is deposited. In the SW Netherlands the latter only occur in places along the North-Sea coast, mainly at the NW side of the islands.

The first ecologist who studied the salt-marsh vegetation in this region was the Belgian VaN LANGendonck (1931, 1933a, 1933b). He gave fine descriptions of the vegetation of some localities along the left bank of the Western Scheldt. After him several local studies on salt marshes were published: Sloff (1936), Vlieger (1938), WeEvers 
(1940), Adriani (1945), Bakker (1950), Westhoff and Beeftink (1950), BAKker and Boer (1957), and BeEfTink (1957).

Studies on the often adjacent beach plains, however, are of more recent date, and some are yet unpublished or appeared in mimeographed form only: Weevers (1940), Mörzer Bruijns et al. (1953), WESthoff, VAN LeeuWen and ADRIANI (1961), RoOsma (1961), and SPEKMAN and Groten (1963).

During the last 15 years the present author has investigated systematically nearly all salt and brackish localities in the area, and his results were published recently (BeEFTink, 1962, 1965). Except the work of Van Langendonck all studies, including those of the present author, were carried out according to the principles of the FrenchSwiss School of BRAUN-BLanQUeT $(1928,1932,1951)$.Van Langendonck used also the Scandinavian method of Du RIETZ (1930).

In the following lines the more classical approach in the ecology of halophytic vegetation will be combined with a cybernetic approach. This latter has been proved to be very useful in ecology, especially in the study of border situations (BEEFTINK, 1965; VAN LeEUWEN, 1965). Therefore, the present paper begins with some theoretical considerations on the cybernetic approach to the ecology of salt marshes, proceeds with a discussion of environmental relations, and ends with a description of the plant communities.

\section{Gybernetic TRENDS In SALT-MARSh ECOLOGY}

In recent years cybernetics has been introduced in ecology. Pioneer work has been done by Margalef (1958, 1961). Van Leeuwen $(1960,1962,1963,1965)$ also started from a cybernetic approach, but has gradually changed this into a more general one, which combines principles from cybernetics with those of the general system theory of Ross AsHBy (1961). A summary of Van Leeuwen's approach was discussed at the 10th International Botanical Congress in Edinburgh (VAN Der MaArel, Westhoff and VAN Leeuwen, 1964). Independently from these authors BLAUT (1960) used the same train of thought in studying the nature and effects of shifting agriculture. In the following lines we will try to use similar arguments in the field of saltmarsh ecology (cf. also BEEFTINK, 1965).

Ecology deals with relations between organisms and their environment. The organisms together with the environment where they are living in, may be grouped into ecosystems. According to BLAUT (1960) the concept of "system" comprises a series of interacting processes. Each process affects all the others, and is maintained by the reflective ("feedback") effect of the other processes as well as by its interactions with external influences across the boundary of the system. The more open the system, the more important the external processes and less important the internal ones, and, correspondingly, the less useful it is to speak of a "system" as such. Ecosystems, as well 
as other systems, thus possess definite and persistent internal integration phenomena (QuAstler, 1959; Ross Ashby, 1961). These integration phenomena represent aspects of internal order or structure subdividing the ecosystem into partial entities or subsystems. The diversity of these partial entities, both in the biotic and abiotic component of the ecosystem, as well as their structural pattern is the result of the action of the above mentioned internal and external relations.

The nature of these joint relations may be defined in terms of stability and instability. According to this point of view two extremes can be distinguished in the environment (TüXEN and WesthoFf, 1963; Van Der MaARel, Westhoff and Van Leeuwen, 1964; VaN LeEuWEN, 1965; BeEFTINK, 1965):

(1) Instable situations characterized by course-grained patterns with sharp boundaries in between; internally homogeneous, externally heterogenous; poor in species and in growth forms. In these ecosystems a low variety-in-space is coupled with a high variety-in-time.

(2) . Stable situations characterized by fine-grained patterns with vague boundaries in between; internally heterogeneous, externally homogeneous; rich in species and in growth forms. Here a high variety-in-space is coupled with a low variety-in-time,

These two types are most obvious as border situations. Instable border situations must then be considered as disturbance zones, noise environments, to which the terms ecotone, stress zone and tension belt are relevant (MozLey, 1954). Stable ones are transitional zones with complex gradient structures. Intermediate types are common as border situations with an instability superposed on a gradient structure. Finally, instable border situations occur, being stable by their constancy in time, e.g. the rocks and cliffs, rising sheer from the sea. The modern anthropogeneous landscape involves many forms of artificial stabilization of instable environments, being brought about by technical civilization and cultivation (VAN LEEUWEN, 1965).

The littoral fringe along the coasts is an example of such an intermediate type. The very long existence in evolution of this border situation, its generally very gradual displacement as well as the regularity in the tidal fluctuations, give this type its stable character. Instability is realized by horizontally directed processes from the outside, crossing the border situation or penetrating into it, e.g. salt spray carried by the wind and flood-water streaming into creeks and inundating the border partially or entirely - with floods caused by earthquakes and tropical hurricanes as extremes. The main instable influences come from the sea-side. Although locally important instable processes such as stagnation of water may occur, the general trend is a gradient of decreasing instability and increasing stability from sea to land and from low to high altitude. The character of this gradient depends firstly on the steepness of the border; so on the very steep slopes of rocky coasts diversity in the direction of the coastline, due to difference in exposition, seems often more important than diversity in vertical direction. The same is the case on exposed beaches (BEEFTINK, 1964). 
On the flat coasts with mud flats, salt marshes and beach plains, stable and instable influences intertwine in a very complicated way, with the instable ones dominating on the sea-side of the border situation and the stable ones dominating on the land side. The principal turning-point between domination of instability and stability lies close to the mean high-water line (MHW). The upper limit of the border situation as a whole lies just above the storm flood zone. Other properties of this border situation will be explained in the section of the genesis of salt marshes. At first hydrographical characteristics of the SW part of the Netherlands will be treated.

\section{HYDROGRAPHY}

Hydrographically the south-western part of the Netherlands must be divided into three parts, viz.:

(1) The complicated Rhine-Meuse-estuary in the north with the Grevelingen, the Haringvliet and the (artificial) Nieuwe Waterweg as river-mouths.

(2) The Scheldt estuary in the south with only the Western Scheldt as river-mouth.

(3) The Eastern Scheldt, a former river-arm of the Scheldt, and its adjacent waters, situated between the two estuaries but nearly completely separated from them.

The complicated hydrography caused the salinity of the water to vary considerably in space and time. In Fig. 2 the mean salinity during high water was classified according to the system accepted at the "Symposion on the Classification of Brackish Waters" in 1958 (Final Resolution, 1959). The isolated position of the Eastern Scheldt involves that its salinity deviates strongly from both estuaries: Before the construction of the secondary dams in the north of the area in 1964 the salinity of the basin of the Eastern Scheldt fluctuated only from 24 to $31 \%$ NaCl (Korringa, 1941). Because of its faunistic and floristic (algal) wealth Den HaRTog (1959, 1961) classified this seaarm, together with the neighbourhood of Flushing and the western part of the Grevelingen, as the (eu-haline) Scaldian district. Concerning the phanerogamic vegetation, however, the Scaldian district cannot be distinguished from the eu-haline and polyhaline zones of the estuaries.

In the estuaries fluctuations in salinity due to alternate domination of salt- and fresh-water flow find their maximum in the mesohalinicum. In the Scheldt estuary this maximum lies closely against the polyhaline zone, between Bath and the Belgian frontier. In the Rhine-Meuse-estuary, on the other hand, we find it at the east end of the isle of Goeree and Overflakkee. During high tides these fluctuations amounts to about 10 and $14 \% \mathrm{Cl}^{\prime}$ respectively throughout the year.

Ecologically these zones of maximum fluctuation must be considered as zones of disturbance. The character of the salt-marsh vegetation 


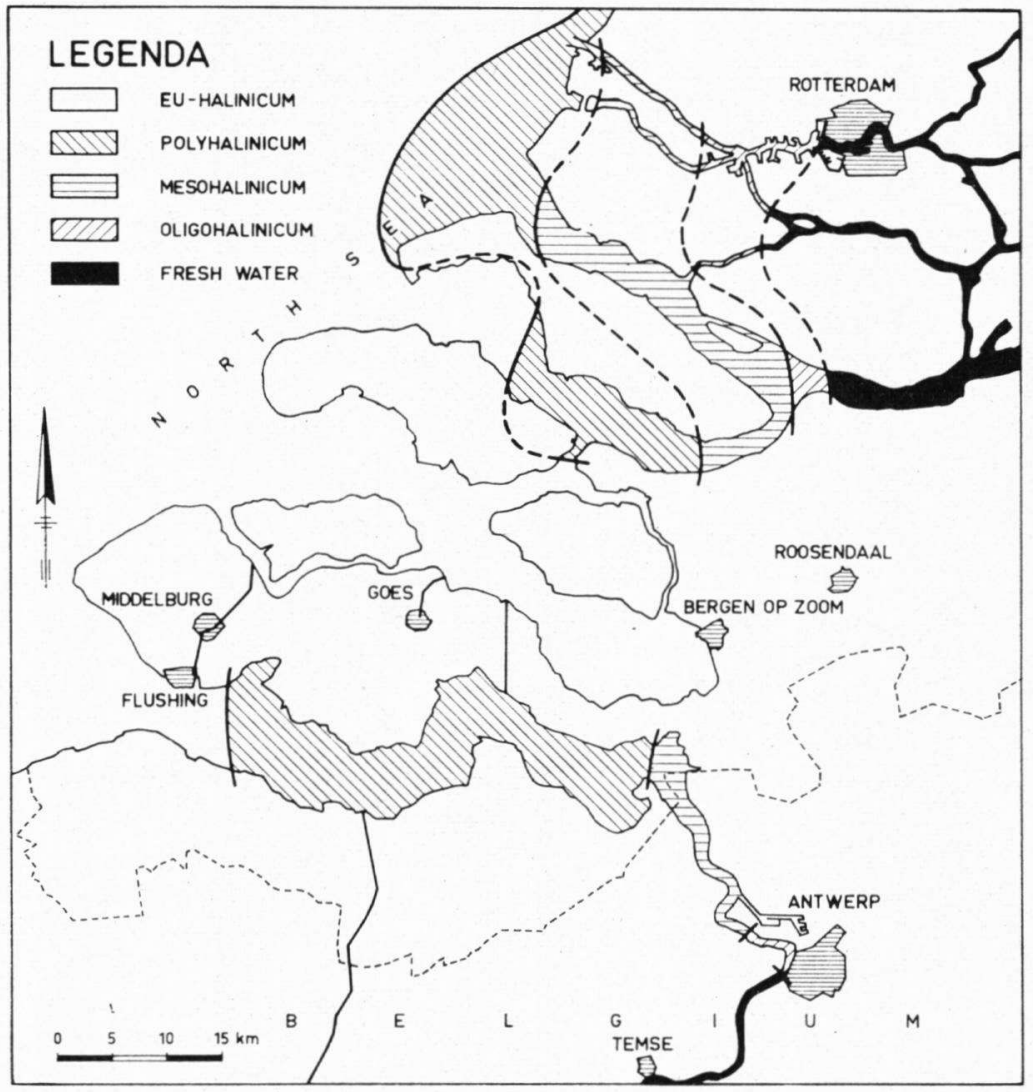

Fig. 2. Classification of the estuaries and sea-arms in the SW Netherlands according to their average chlorinity at high-tide.

agrees with this instability, for in this zone the number of species reaches its minimum while the monotonous coarse-grained type of structure characterizes the whole vegetation. The eu-halob halophytes Spergularia marginata, Limonium vulgare, Halimione portulacoides, Artemisia maritima, Suaeda maritima, and, less pronounced, Salicornia europaea penetrate the estuaries not farther than the inner limit of the polyhaline zone. In the Scheldt estuary upstream of the centre of the "noise" environment we find species such as Cochlearia officinalis, Sonchus arvensis, Calystegia sepium, Rumex crispus, Althaea officinalis (rare), Cirsium arvense, Solanum dulcamara, Alopecurus geniculatus, Trifolium fragiferum, Hordeum secalinum, Festuca arundinacea, Plantago major, and Lolium perenne on the marshes. In the Rhine-Meuse-estuary the whole Haringvliet must be considered as a disturbance zone, for everywhere its maximum fluctuations in salinity during high tides exceed $10 \% \mathrm{Cl}^{\prime}$ (according to data kindly placed at the author's disposal by Mr. R. Peelen, Yerseke). 
For this reason the last mentioned species are also found from Willemstad downstream to about the polyhaline limit. The broad banks of this river-arm and its slighter pollution, however, result in a much better development of the communities of these species.

Separate from this negative aspect of the estuarine instable environment there is, however, also a positive one: For some special taxa the disturbance zone offers an optimal habitat. In the first place Puccinellia fasciculata, $P$. distans and Spergularia salina belong to these "noise" species. Although the latter two also occur in the polyhaline and more rarely - in the eu-haline zones, they develop optimally on salt marshes only in the $\alpha$-mesohalinicum (flood-water average $10-5,5 \%$ $\left.\mathrm{Cl}^{\prime}\right)$. Outside the dikes, Puccinellia fasciculata is even restricted to localities with the most extreme fluctuations in salinity: Whereas on the landside of the dikes this species is common on (beaten) places with large salinity fluctuations, it occurs outside only on the east coast of the isle of Goeree and Overflakkee (BEEFTINK, 1965) and on the left bank of the Western Scheldt near the Belgian frontier (VAN GRIETHUYsen, 1964). In addition, taxa confined to the disturbance zone in a broader sense are Scirpus maritimus var. compactus (Hoffm.) G. F. W. Meyer, Cochlearia officinalis and Althaea officinalis.

Along the coasts of the North Sea the average tidal difference varies from about $3.80 \mathrm{~m}$ near the Belgian frontier to $1.50 \mathrm{~m}$ near Hook of Holland. In the estuaries, however, it increases considerably as a result of stowing of the tidal waves between the estuarine dikes, and the counter-pressure of the river-flow. In the Scheldt estuary, for instance, the mean tidal difference increases from $3.60 \mathrm{~m}$ near Flushing to about 5.- $m$ near Antwerp. Proportional of this increase of the tidal wave the level of the salt marshes, and of their plant communities rise gradually upstream (cf. the average levels in Fig. 4).

\section{Genesis of SALt MARShes}

In the SW Netherlands the low soils of the eu-littoral zone consist of sand and mud flats separated by large channels. According to $V_{\text {AN }}$ Bendegom (1950) these shallows and channels originate essentially by lateral transport of sand and silt: From two tide-runs situated side by side and having a different velocity of current (in Fig. $3 \mathrm{~A}$ the tideruns I and II or II and III) and consequently also a different sand and silt content, the tide-run carrying the higher content will lose material to the tide-run with the lower content. Consequently, in the receiving tide-run sedimentation takes place while the other one often erodes. Finally, with a certain slope of the bottom an equilibrium is reached depending on the difference in transport of material in the tide-runs.

In cybernetic terms this process means that from contact between two differentiated entities (the tide-runs) via transfer of information (lateral transport of materials) a second differentiated situation (difference in ground-level) arises. 

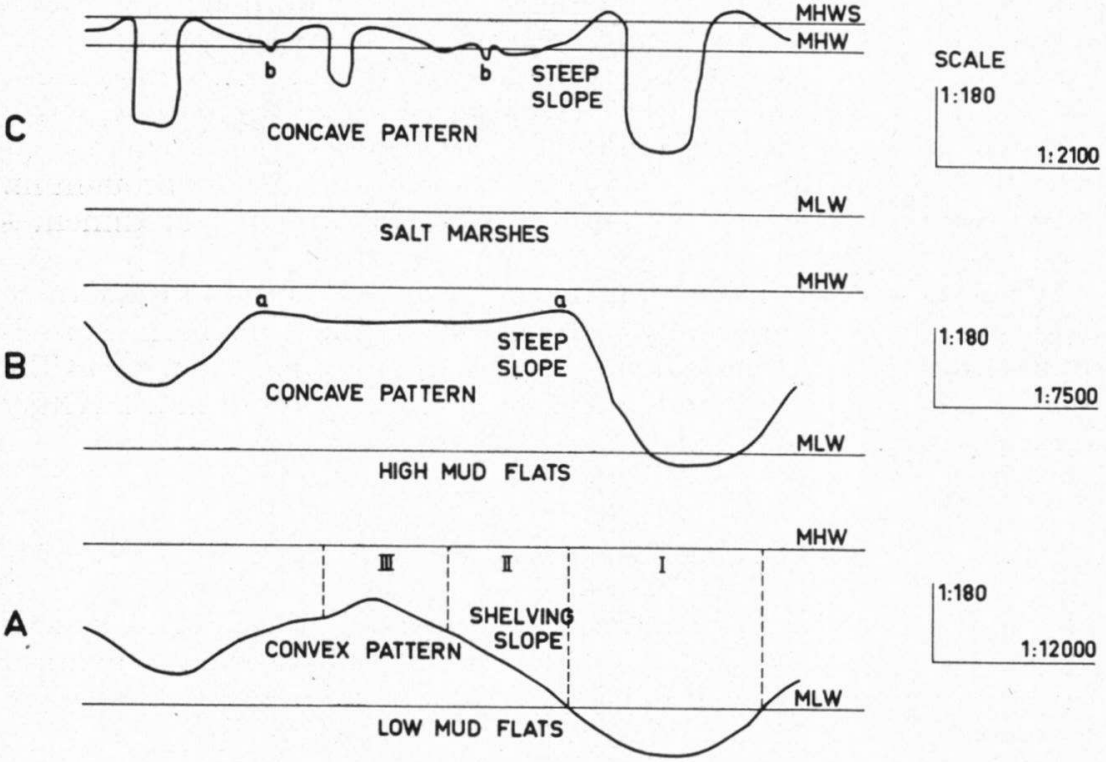

Fig. 3. Genesis of salt marshes from mud flats. Explanation in the text.

At this initial stage of development the geomorphology is highly defined by the levelling effect of the tide-runs forming the horizontal component of the tides. Only the coarsest differentiations persist more or less. Thus the system is instable and coarse-grained. The sand and mud flats are convex and the channels have shelving banks (Fig. 3A).

With continued sedimentation the water-layer covering the shallows during high tides will gradually diminish. In the course of this process a gradual decrease of the velocities of the tidal currents and of the distance of horizontal transport of sand and silt in lateral direction take place. Consequently, the concentrations of sedimentation which in the beginning gave the shallows their convex model diverge to the edges (formation of creek banks: a in Fig. 3B). At the same time the shelving slopes of the creeks modify into steep ones.

Parallel to divergence of the concentrations of sedimentation the concentrations of erosion (channels) diverge too: As sedimentation proceeds the creeks split up more and more, and penetrate into the shallows, now becoming marshes, by erosion. In this way the marshes are more and more devided into partial entities (Fig. 3C).

Genesis of salt marshes from sand and mud flats thus leads to the formation of a large number of deposition and erosion concentrations. From a coarse-grained instable system of shallows and channels an increasingly stable, fine-grained system of marshes develops.

Inversion of the soil-relief from a convex to a concave model also changes the single process of deposition into two different processes. 
The spatial decrease of the lateral transport of material creates a second type of transport, intercalating the divergent first one. The inverted shallows will thus receive material from two directions: (1) Via water flowing over the creek banks; here the sediment will mainly consist of sand. (2) Via the smallest ramifications of the creeks (b in Fig. 3G); in this way chiefly clay and silt particles are brought in. These two processes are distinguished as lateral and apical sedimentation respectively.

When the creek banks silt up very highly the accretion rate of these banks will decrease gradually with respect to that of the basins, providing supply of clay and silt is sufficient. These final changes in the relation between lateral and apical sedimentation result in a levelling tendency of the soil-relief.

\section{Physical and chemical aspects of the soll}

The increasing divergence of the environmental pattern during genesis of the salt marshes is also manifest in several physical and chemical aspects of the soil. We will touch here some of them shortly; for more detailed discussion cf. BEEFTINK (1965).

\subsection{Soil texture}

During genesis of the salt marshes sedimentation of clay and sand takes place more and more in separated processes. In the basins especially clay and silt are deposited, as soon as apical sedimentation sets in. On the other hand the creek banks are mainly built up by sand and silt as a result of lateral sedimentation. The more sand takes part in the sedimentation of salt marshes the more pronounced the differences in level between creek bank and basin will be. On the other hand prevailing supply of clay and silt has a levelling influence on the soil-relief. In view of the great importance of the larger creeks as media for sedimentation of sand, field-draining operations carried out at an early stage and obviating the sedimentation by way of the creeks will exert a levelling influence.

The most easily desiccating and leaching deposits are thus found on the highest levels. This phenomenon intensifies once more the ecological contrasts already caused by vertical differences. As we shall see the variety in vegetation reflects this environmental differentiation.

\subsection{Carbonates}

In the salt marshes the carbonates show a pattern also following the differentiation caused by lateral and apical sedimentation. Concerning the relation between carbonate and clay content it is possible to distinguish two series separated in space: (1) the series of the creek banks in 
which carbonate content increases with clay content, and (2) the series of the basins in which this relation is negative (cf. also VERHOEVEN, 1963). It must be taken for granted that in the basins decalcification takes place by excess of carbon dioxide - formation of bicarbonates produced by respiration of the roots and decomposition of organic material, and that stagnant water impedes its evasion. During this process the finer carbonate particles will be affected in the first place.

\subsection{Soil moisture, ground-water movements, and aeration}

The water relations in the soil are obviously of considerable importance, as many plants react strongly on the ground-water situation. Even on saturated soils in the eu-littoral zone the measure in which the young sediments are water-logged is a factor of primary importance for the establishment and growth of several phanerogams: In our area Zostera marina var. stenophylla A. et $\mathrm{G}$. is only found on weak, mostly clayey deposits, while Zostera nana only forms a close vegetation when the soil is relatively firm. Also Salicornia stricta does not grow on weak soils, but on the other hand Spartina townsendii grows well on muddy soils.

In the salt marshes, the water-pressure in the underground is determined by the tides. The more or less clayey sediments in the upper 1-1.5 m of the soil profile rest nearly always on a sand layer (generally $3-10 \%$ particles $<16 \mu$ ) of a thickness of several meters. The latter is pervious to tide-water, providing it is not covered by silty sediments in its contact zone with the open water. The unaerated parts of the clayey deposits, however, are almost impervious to water (Fokkens and De Koning, 1960). As the clayey deposits retain water most strongly, the periodic pressure fluctuations of the ground water in the sand layer under them seem to be sufficient to prevent them from losing their water contents, although tidal fluctuations in these water contents are absent.

The diurnal pressure fluctuations in the sand layer, however, are not of the same magnitude everywhere. In the first place they depend on the resistance of the sand layer. Consequently, they decrease with increasing distance to the open water. It appears that in the basins at neap tide fluctuations were unmeasurable at a distance of e.g. 240-280 $\mathrm{m}$ from the open water. At spring tide, however, the pressure waves penetrate much farther inland. Together with the gradual decrease of these pressure waves in a landward direction, the aerated soil layer in the basins diminishes gradually.

Besides the above mentioned system of gradually decreasing fluctuations in the ground-water pressure in a direction perpendicular to the coast-line, there is another, more variated system. If a creek is deep enough to touch the pervious sand layers, its water contents during high tide will add pressure to the water in the underground of the adjacent creek banks, which pressure will rapidly decrease towards the 
basins. Consequently, the pressure fluctuations in the underground of the big creek banks are much larger than in the underground of the basins. However, these fluctuations show greater differences from basin to basin than from creek bank to creek bank.

In the smaller creeks communication of flood-water with water in the underground to a single pressure system is impeded, as their beds all get stuck in unaerated silty or clayey sediments. In deeper creeks, too, communication may be impeded as soon as silt is deposited, e.g. by silting up of their mouths, by caving in of the creek banks or as a result of retardation of the tide-runs by establishment of Spartina townsendii in the creeks. Direct lateral movement of water through the creek banks seems insignificant except above the level where the soil is aerated.

In the upper layers of the salt marsh the moisture and air content depend mainly on: (1) evaporation and transpiration of the vegetation, (2) precipitation, (3) submergence by flood-water, and (4) the pedogenetic state of the soil, as well as its texture. In water-saturated soils of eu-littoral mud flats flood-water cannot penetrate far. However, when the emersion periods are long enough, such as in the terminal phases of the Salicornietum strictae, the top layer may temporarily dry up. These circumstances favour establishment of other halophytes, e.g. Puccinellia maritima, Aster tripolium, Suaeda maritima, Triglochin maritima and Limonium vulgare. These plants withdraw water from the soil for transpiration and thus promote aeration further while at the same time sedimentation goes on. These processes lower the borderline between aerated and unaerated soil, and induce shrinkage and regrouping of materials and pores. It has been found that in the basins covered with the Spartinetum townsendii and the Puccinellietum maritimae, and situated up to $35 \mathrm{~cm}$ above mean level of the Salicornietum strictae on the mud flats, soil aeration extends to $55 \mathrm{~cm}$ deeper than in the latter association. In the creek banks the soil is aerated much deeper, though the aerated layer is about as deep as in the basins with respect to Dutch Ordnance Level.

As Chapman $(1938,1960)$ stated only part of the air escapes from the marsh soil during submergence by the flood, and is replaced by floodwater. At the same time, however, the water pressure in the aerated soil layer during high tide is level with the surface of the overflowing water. The rise of the soil-water table in this layer occurring anyhow, is not caused by supply of water from the underground, for the underlying unaerated clayey sediments are nearly impervious, but by supply from overflowing water and, probably to a much lesser extent, by penetrating the creek banks. In the marsh soil and its vegetation we find thus an ecosystem, in which the input of water, mainly derived from above by flood and precipitation, is more or less balanced by the outflow of water from the aerated layer through the creek banks, combined with evaporation and transpiration. The few floods inundating the marsh during the period of spring tides thus bring as much water into the upper soil-layer as flows out through the creek banks and evapo-transpirates during two weeks. The result of this balance, 
the border-line between aerated and reduced layer, may fluctuate owing to seasonal variations in input and output.

\subsection{Salinity}

The salinity of the soil is closely related to the water relations. Since on the european-atlantic coasts the annual precipitation mostly exceeds the annual evapo-transpiration, the regulating function of submergence on the whole results in an input of salts. Only in summer, when the salinity of the soil solution temporarily exceeds that of the flooding water, submergence will have a leaching effect.

On higher localities with respect to the tides the salinity of the soil moisture balances round ever lower average levels. Together with the decreasing duration of the immersion periods also the influences of the opposite effects of precipitation and evapo-transpiration on salinity increase. These influences reach their maximum when the salinity level in the soil is relatively high; in other words with respect to MHW there is a level above which the opposing effects of precipitation and evapo-transpiration on the fluctuation of salinity decrease again because the average salinity level becomes too low. According to analyses of soil samples these maximum fluctuations are found in a well-developed salt marsh between $25-35 \mathrm{~cm}$ above MHW, which means in the border between the associations Puccinellietum maritimae and Halimionetum portulacoidis, which border coincides with the border between apical and lateral sedimentation territories respectively.

Up the estuaries the annual fluctuations in salinity of the flood-water become more and more an important factor. For this reason the salinity of soil moisture tends to show larger fluctuations in upstream directions. However, the opposing effects of precipitation and evapotranspiration tend to diminish upstream because the salinity level gradually drops. The result of these opposing tendencies is that somewhere along the estuary the amplitude in soil salinity reaches a maximum value. The position of this maximum depends on the intensity of the individual effects. As we have already seen the effect of the flood water decreases and that of precipitation and evapo-transpiration increases as the level of the soil surface lies higher with respect to MHW. The ultimate result is that the maximum amplitude of soil salinity will be situated farther downstream, the more the soil surface lies on higher levels with respect to MHW. This theoretical approach has been confirmed by analyzing soil samples from several localities along the Western Scheldt (BEefTink, 1965, p. 47).

Thus we find that up an estuary a certain amplitude in salinity of the soil moisture gradually shifts to lower levels with respect to MHW. In the vegetation similar shifts are found: Species such as $A$ grostis stolonifera, Juncus gerardii, Glaux maritima, Atriplex hastata, Spergularia salina and Puccinellia distans, in the mouth of the Scheldt estuary limited to the higher parts of the salt marshes, grow at lower levels farther upstream, as Miss Gillham (1957) also found for Agrostis stolonifera in the Exe estuary. 


\subsection{Supply of organic matter}

Besides soil texture, soil moisture, aeration, and salinity the nitrogen level must be considered to be a master-factor. The supply of organic matter by the tides, either from the salt marsh itself or from far away, is the most important factor determining the nitrogen level of the habitats.

Two different kinds of supply of organic matter to the soil must be distinguished: (1) a more or less uniform "basic" supply with autochthonous organic matter and with more or less humous materials incorporated into the sedimentation process, and (2) a differentiated "extra" supply showing different concentrations both in space and in time.

The latter can be subdivided into two parts according to the way it is washed ashore: (a) Tidal drift consisting of algae floating in the water such as Ulva lactuca, Porphyra umbilicalis, Chaetomorpha linum, and Enteromorpha spp., and scattered over high mud flats as well as on low salt marshes, especially against obstacles such as creek banks and Spartina clumps. (b) Tidal drift consisting of rests of phanerogams, especially of Spartina townsendii, Elytrigia pungens, Halimione portulacoides, Festuca rubra, and, in the brackish parts of the estuaries, of Scirpus maritimus and Phragmites communis, and of detached large Phaeophyceae (Fucus spp., Ascophyllum nodosum and Laminaria saccharina). These rests float on the surface and wash ashore in concentrated belts at the upper parts of the salt marshes and beaches, especially at the foot of dikes and dunes, and on bars and high creek banks.

The first type of tidal drift will cover large surfaces, e.g. some hectares; thick belts are rare. It is washed ashore in the late summer and in autumn, and is decomposed nearly entirely the next spring. On soils covered by this type of tidal drift, especially Suaeda maritima develops. IIts property of germinating in light (KINZEL, 1926) agrees with the decomposition of the algae in spring. Suaeda maritima, however, is also found forming a community on the other type of tidal drift, but then only when it is thin, remains continuously wet and decomposes rapidly (cf. also DaHLBECK, 1945, p. 47 and 78).

The tidal drift consisting of parts of phanerogams and large Phaeophyceae is washed ashore in late autumn and in the winter months, sometimes also in early spring, and decomposes to humous material after a lapse of one or more years. When this tidal drift is covered by windblown sand as is often the case on beaches, the following species develop: Honckenya peploides, Cakile maritima, Salsola kali, Atriplex sabulosa, A. glabriuscula and A. hastata (Salsolo-Honckenyon peploidis). Mostly, however, this material remains uncovered. When it has been deposited at the foot of the dikes and on high creek banks the dominants are Atriplex hastata and $A$. littoralis and their principal companions Elytrigia pungens, Matricaria inodora, Sonchus arvensis and Beta maritima (both latter species especially in the neighbourhood of dunes), Cirsium arvense (takes the place of both the Atriplex-species in the meso- and oligohaline zones), Elytrigia repens, Potentilla anserina a.o. When tidal 
W. G. BEEFTINK: Salt marshes and beach plains

SCHELDE-ESTUARIUM

Sagineto maritimae-

$\mathrm{cm}$ Cochlearietum danicae

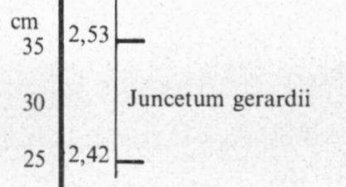

\begin{tabular}{l|l}
20 & Atripliceto- \\
15 & Elytrigietum pungentis
\end{tabular}

02,

$-10$

$-15$$$
-20
$$

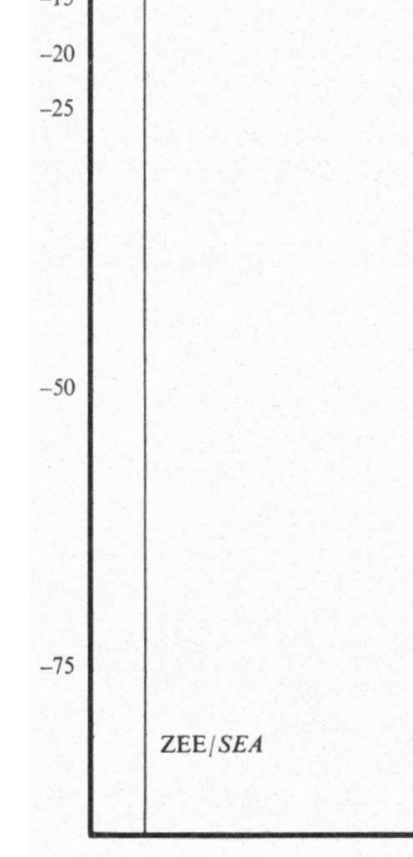

Ellewoutsdijk

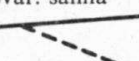

2,22

$5 \longdiv { 2 , 2 2 }$ SCHELDT ESTUARY

Agrostis stolonifera

$$
\text { ELDT ESTUARY }
$$

Agrostis stolonifera
subvar. salina
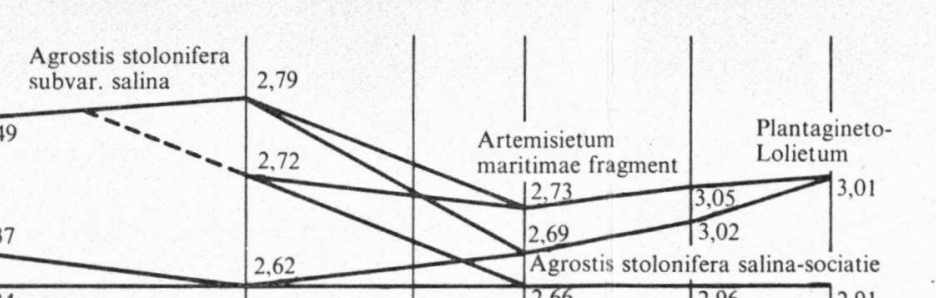

acoidis

2,37

2,34 2,66
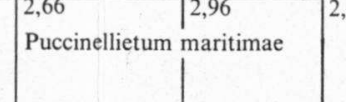

2,91 P. maritimae

initiale phase met

Spartina maritima

STERSCHELDE-BEKKEN EASTERN SCHELDT

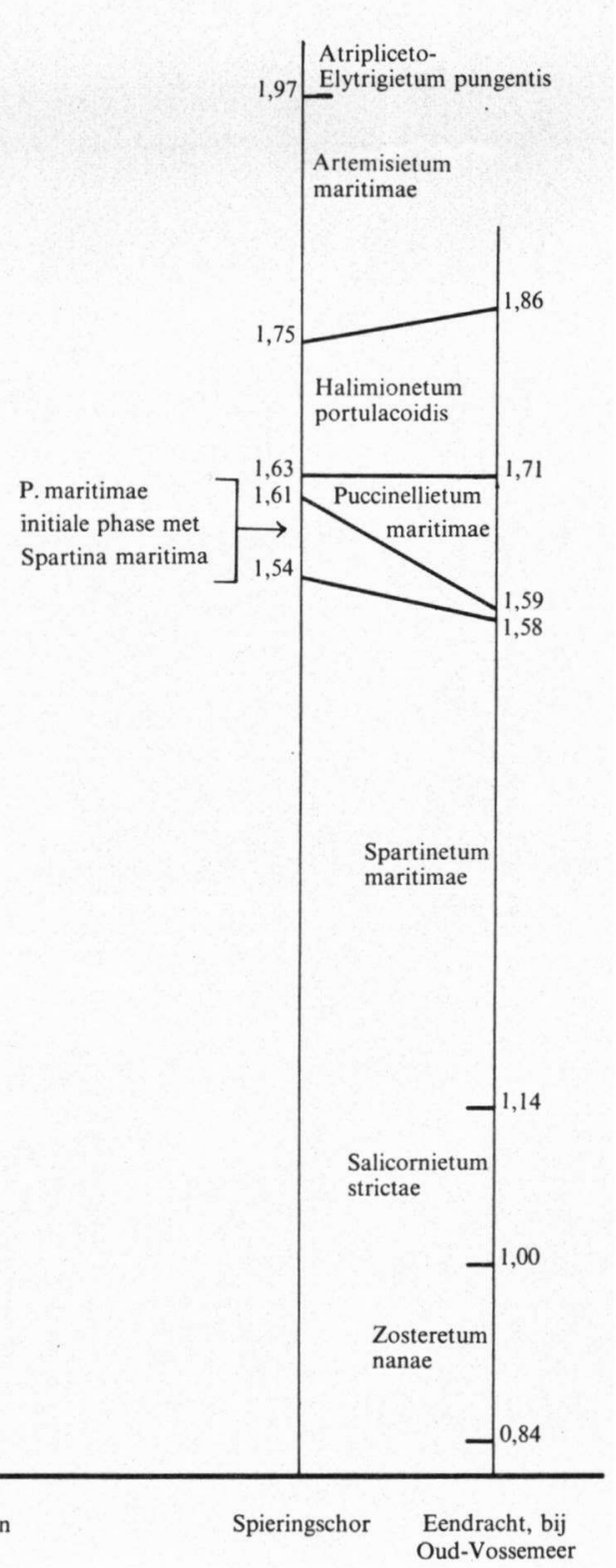

Facing p. 96.

Fig. 4. Zonation of the principal communities along the estuary of the river Scheldt and along the Eastern Scheldt. Each measured boundary-line is indicated by its average level above NAP (Normal Amsterdam Level, Ordnance Datum). Ordinate: level with respect to the average upper limit of the Puccinellietum maritimae. Abscis: the localities investigated, for the estuary of the river Scheldt on scale $1: 435.700$. 
Survey of the principal succession series on mud flats and salt marshes in the SW-Netherlands.

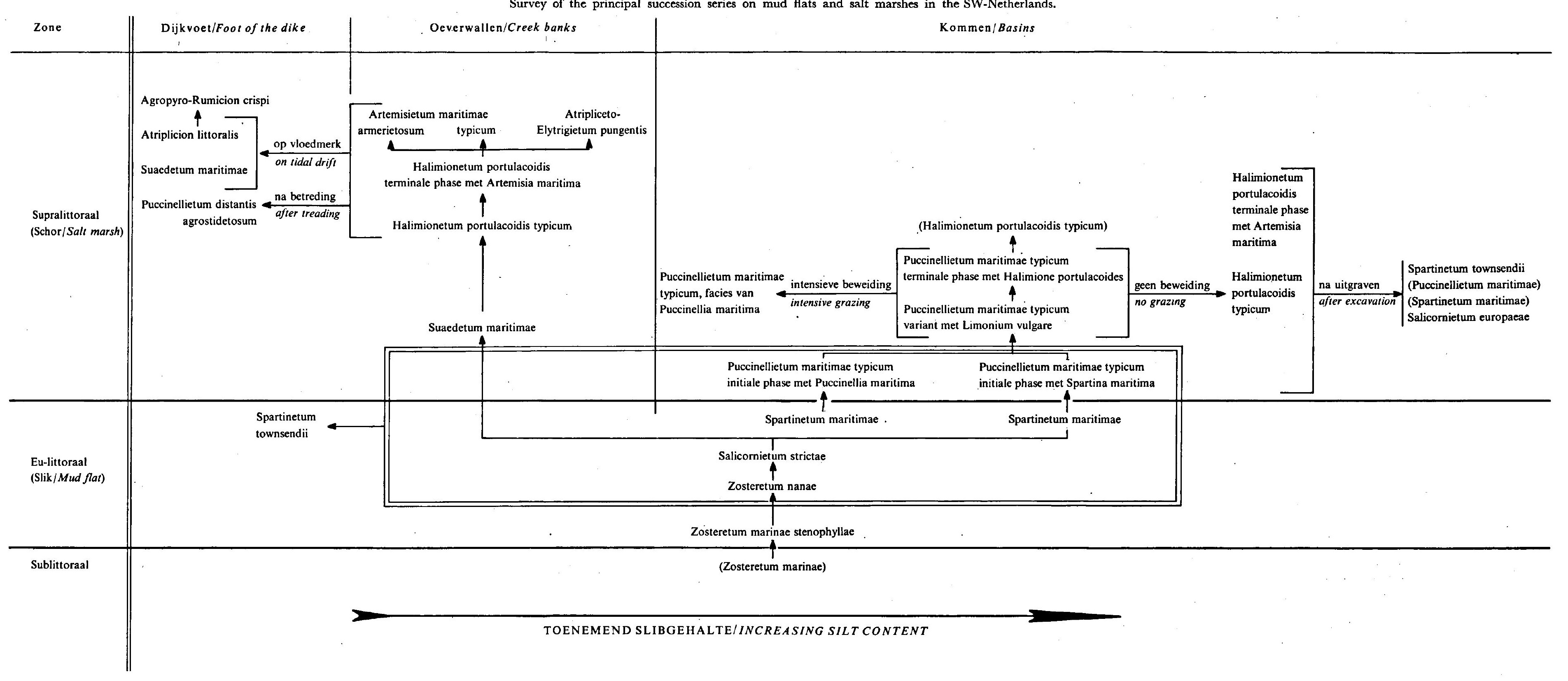


TABLE 2

Survey of the principal succession series on beach plains in the SW-Netherlands.

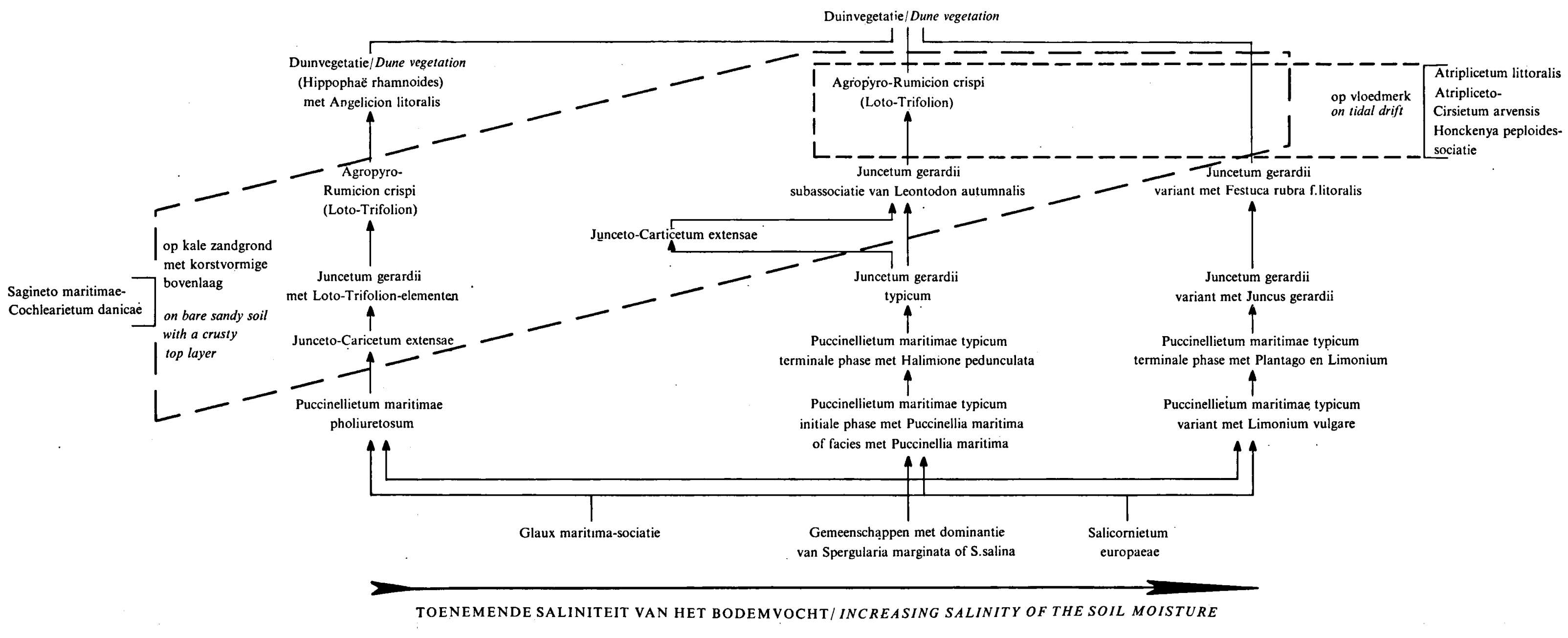


drift is no longer supplied these Atriplex-communities decline, at first in vitality, later on also in density, while species characteristic of the orders Plantaginetalia maioris and Calystegietalia sepii develop abundantly.

On beach plains tidal drift may be thrown in brushwood of Hippophae rhamnoides. Then Angelicion litoralis-communities develop in it. Characteristic species are a.o.: Elytrigia pungens, Calystegia sepium, Cirsium arvense, Sonchus arvensis, Althaea officinalis and Angelica archangelica ssp. litoralis (Fries) Thellung. On creek banks in mesohaline reed marshes similar communities develop, characterized by Cochlearia officinalis and Oenanthe lachenalii in addition to the majority of the above mentioned species.

Since tidal drift is washed ashore in an existing vegetation the communities mentioned before are often mixed with remnants of the original vegetation. It seems that this phenomenon is frequent in disturbance zones.

\section{The vegetation ${ }^{1}$ )}

\subsection{Zonation and succession}

Fig. 4 represents the zonation of the principal syntaxa ${ }^{2}$ ) on the salt marshes along the Scheldt estuary and on some localities in the Eastern Scheldt. On all localities the boundary-lines of each syntaxon were levelled several times. In the figure their average values are indicated with respect to the Dutch Ordnance Level (NAP). The diagram illustrates three phenomena:

(1) The phenomenon that upstream the plant communities grow on gradually higher levels, apparently proportionate to stowing of the tidal waves in the estuary.

(2) Variation in the vertical range of taxa and syntaxa along the estuary, e.g. a landward decrease resp. increase of the ranges occupied by the associations Halimionetum portulacoidis and Artemisietum maritimae.

(3) Inversion in zonation of Agrostis stolonifera subvar. salina $\mathrm{J}$. et W. and Festuca rubra f. litoralis Hackel ( $=F$. rubra var. pruinosa (Hackel) Howarth?) between the localities Waarde and Ossendrecht. Miss Gillham (1957) found the same inversion along the Exe estuary. Other species growing on lower levels in a landward direction and therefore also showing inversion phenomena, are Glaux maritima and Juncus gerardii. Other inversion phenomena are shown by Juncus maritimus with respect to Elytrigia pungens and by Puccinellia fasciculata with respect to $P$. distans.

Inversion phenomena as well as variations in the vertical range in

1) For detailed discussion of the ecology and distribution of the mud-flat and salt-marsh communities of Western Europe and of the classification of these communities according to the French-Swiss School, the reader is referred to BEEFTINK (1965). A survey of these communities growing in the Netherlands with short notes on ecology and distribution is also given by BEEFTINK (1962).

2) By a syntaxon is understood every abstract vegetation unit defined floristically (BARKMAN et al., 1958). 
the zonation are common in border situations. They occur also in the salt-marsh vegetation along the Westeuropean coasts (BEEFTINK, 1965). They seem to be related to the sequence and magnitude in which certain environmental processes are spatially combined. In the case of the littoral fringe especially combinations of salinity and soil-moisture relations are relevant. In this respect average level and variety-in-time of these factors are equally important.

These phenomena are the reflection of some of the internal integration aspects of the environment in the border situation. By these internal integration aspects the ecosystem is divided into niches, realizing patterns in growth and in population distribution.

The study of succession is a very difficult one for the danger exists that one considers zonation as the spatial expression of succession. Communities situated close to one another in the landscape may be stages of different succession series. The Tables 1 and 2 show the succession series of the vegetation on salt marshes resp. beach plains in the SW Netherlands.

On the mud flats there is hardly or only partly question of succession. Between the Zosteretum marinae stenophyllae and the Zosteretum nanae sometimes succession of a cyclic character may be observed (cf. also Den Hartog, 1958). Although the Zosteretum nanae touches often the Salicornietum strictae, the latter must be generally considered as a pioneer vegetation in the same way as the Spartinetum maritimae. Spartina townsendii, a species originated in recent times (e.g. LAMBERT, 1964), forms an element of disturbance. Firstly, it has not yet found its definite, epharmonic place in zonation and succession. The process realizing the occupation of this epharmonic place will involve loss of gene material within populations of the species ousted, especially Spartina maritima and Salicornia europaea. However, the consequence of its appearance for further succession of salt-marsh vegetation will also be radical, because it influences the environment strongly. So it modifies geomorphological development and counteracts spatial differentiation in soil factors. Although examples of further succession are not yet known, it can be predicted that succession stages comparable to those in undisturbed vegetation will not follow. Halimione portulacoides seems to be most likely to characterize the following stage, especiaily because usually there will be no grazing.

As soon as the sedimentation process diverges into a lateral and an apical one, also succession diverges into a series on the creek banks and another one taking place in the basins (Table 1). In the first succession series the Halimionetum portulacoidis and, later on, the Artemisietum maritimae are the most important associations. During the second one the rather variable Puccinellietum maritimae develops. Extensive grazing promotes diversity in these associations and thus adds information to the ecosystem. Intensive grazing as well as excavation of the marshes lead to regression. In the long run no grazing leads also to loss of information, finding expression in a more monotonous vegetation. STÄRCKE (1944-45) has pointed out that differentiation in grass-land vegetation is the result of mutual adaptation between herbivorous 
mammals and vegetation, and that this vegetation will impoverish when there is no grazing at all.

On tidal drift the Suaedetum maritimae and communities of the alliance Atriplicion littoralis will develop. When tidal drift is washed ashore in small quantities, as is mostly the case on creek banks, the AtriplicetoElytrigietum pungentis will develop out of the Halimionetum portulacoidis and the Artemisietum maritimae. Treading, mostly taking place on the higher parts of the salt marshes on the level where tidal drift usually is deposited, gives the soil a compact structure, resulting in strongly fluctuating salinity and moisture contents on places without vegetation. These habitats may be favourable for communities of the alliance Puccinellieto maritimae-Spergularion salinae, characterized by a.o. Spergularia salina, Puccinellia distans, and $P$. fasciculata.

On beach plains the succession begins with different communities depending on salinity of the soil moisture often coupled with accessibility for sea-water. Here, too, the top-soil may be compact owing to stagnant water. As on the salt marshes different succession series may develop, here as a result of differences in salinity and in the occurrence of stagnant water. In Table 2 three series are given, having the transition from the Puccinellietum maritimae to the $\mathcal{F}$ uncetum gerardii in common. However, in each series these associations show different subordinated succession stages, being distinguished as variants or phases.

In the transition zone between beach plains or salt marshes, and dunes or sandy bars, special environmental circumstances occur. This zone, being the upper limit of the littoral fringe, forms the border situation between salt and fresh land. The character of this border situation is essentially one of disturbance or stress, induced by irregular flooding during storms. Its nature depends further on the texture and moisture content of the top-soil, and on supply of tidal drift.

Sandy soils in this zone may often show sharp desiccation in spring and early summer, together with extremely high salinity and a crusty top layer. On these habitats communities of the alliance Saginion maritimae (Sagineto maritimae-Cochlearietum danicae) develop. On more silty soils communities of the alliance Agropyro-Rumicion crispi (LotoTrifolion) bears witness of the irregularly alternating marine and fresh water (precipitation, seepage) influences. Some characteristic species of these communities often penetrate into the funcetum gerardii (e.g. funcetum gerardii, subassociation with Leontodon autumnalis). Into this situation deposition of tidal drift may introduce a further form of instability. This factor involves establishment of Atriplex species, Honckenya peploides, Sonchus arvensis, Beta maritima, Cirsium arvense, Elytrigia pungens, a.o. The perennial species among them show a high residuary value with respect to tidal drift: They are able to maintain several years when tidal drift is no longer washed ashore on the very level where they grow. Finally, under brackish circumstances brushwood of Hippophae rhamnoides may grow in the storm flood zone, consequently tidal drift is thrown into it. In that case communities of the alliance Angelicion litoralis develop. 
In the residuary value of perennial species with respect to tidal drift we meet with one of the features of the vegetation characteristic of stress situations. Owing to these situations the species must be adapted to the disturbances at issue, finding expression in properties to resist unfavourable circumstances and survive (feedback arrangements). In this respect abundant formation of seeds, flower formation of dwarf forms, an effective dissemination, longevity of seeds, the being of a winter-annual, formation of rosettes, and creepers are of importance.

Here we cannot speak of succession in the proper sense of the word. The salt marshes and beach plains on the one hand, and the dunes and sandy bars on the other hand develop in separated ways: The first ones by deposition of silt and sand by the flood, the second ones by accumulation of blown sand. The instable border situation is thus wedged in between two ecosystems, differing widely in their genesis and vegetation. The peculiarity of this border situation is expressed in Tuxen's terms "Teppich-Gesellschaften" (carpet communities) for AgropyroRumicion crispi- and Polygonion avicularis-communities (also relevant to Saginion maritimae-communities) and "Schleier-Gesellschaften" (veil communities) for Angelicion litoralis-communities (TüxeN, 1950). From the view-point of time he speaks of "accordion" or "shuttle"-succession referring to the precarious character of the border situation (TüxEN, 1950, 1957; TÜXEN and WESTHOFF, 1963).

\subsection{Plant communities on mud flats}

As has been stated in section 4 the habitat of the eu-littoral zone is mainly characterized by the tide-runs. Against this horizontally directed action the vegetation is adapted by supple sprouts (Zostera spp.) or by stiff, erect growth forms (Salicornia stricta, Spartina spp., Scirpus spp.). Moreover, the individuals or sprouts of the different species occur in large quantities, sometimes with great density ("masseffect" sensu ZoNNEVELD, 1960). The populations of most species hardly intermingle. Consequently, chiefly monospecific, internally very homogeneous communities with sharp boundaries can be distinguished. Only Suaeda maritima often traverses this type of pattern, growing on habitats of various dimensions fed by algae washed ashore. The communities of the mud flats thus show but little floristic affinity to one another. Consequently, they have to be classified into three alliances separated completely in the hierarchic system of classification categories.

The alliance Zosterion extends in the eu-haline and polyhaline zones of the coastal waters. It is represented by three associations:

(1) The Zosteretum marinae, growing in the sublittoral, has been much damaged by the mysterious epidemic of 1930-34. As a result of the subsequent erosion of the habitats it became very rare in the Netherlands. In the SW part of the country, however, there are no indications that Zostera marina ever grew in numbers in the past, 
probably owing to the mobility of the substrate as a result of strong tide-runs. The association is only found in the canal connecting the harbour of Goes with the Eastern Scheldt.

(2) The Zosteretum marinae stenophyllae, developing on muddy soils in the eu-littoral zone, is rather common in our region. In winter all or nearly all rhizoms of the characteristic and dominant taxon, Z. marina var. stenophylla A. et G., are killed by frost. Consequently, the association is annual.

(3) The Zosteretum nanae, developing in the upper half of the eulittoral zone, on generally firmer and, during the periods of emergence, drier parts of the mud flats than the former associations. It is rather common as well.

In summer these eel-grass associations are often interwinded with wreaths of free-living algae, such as Chaetomorpha linum, Entermorpha spp., Ulva lactuca, Porphyra umbilicalis, a.o. Zostera hornemanniana, distinguished by Turis $(1936,1942)$, has neither been found in the field, nor in herbaria of the Netherlands.

The second alliance, the Thero-Salicornion, comprises pioneer communities of annual Salicomia's, occurring on high mud flats and in low parts of salt marshes and beach plains of the eu-haline and polyhaline zones, as well as bordering saline creeks, pools and lakes on the landside of the dikes. Within the faithful taxon, Salicomia europaea coll., a number of species or subspecific taxa, growing on different habitats, have to be distinguished. Therefore it is possible to recognize a number of associations or lower ranked syntaxa. Of these the Salicornietum strictae has been recognized, growing exclusively within the daily reach of the tides. This association was formerly very common; nowadays it is only locally well-developed, as it was ousted in many places by Spartina townsendii.

The third alliance, the Spartinion, comprises pioneer communities of salt and brackish coasts as well. In the Netherlands two associations occur:

(1) Spartinetum maritimae. Grows in a narrow zone closely below MHW, on mud flats as well as in the lower parts of the basins. Spartina maritima reaches the northernmost limit of its area of distribution on the south coast of Goeree and Overflakkee. Formerly common, but at present nearly entirely ousted by Spartina townsendii.

(2) Spartinetum townsendii. Develops optimally on soft, water-logged mud, and penetrates into the $\alpha$-mesohalinicum. Since 1925, Spartina townsendii has occupied vast areas of mud flats and low salt marshes, thus eradicating many other associations (cf. Table 1).

In the mesohaline zone and upstream Scirpus species form pioneer communities. At first Scirpus maritimus var. compactus (Hoffm.) G. F. W. Meyer appears, often occupying vast areas on the mud flats of the $\alpha$-mesohaline subzone. In the $\beta$-mesohaline subzone this taxon is 
gradually replaced by Scirpus lacustris ssp. glaucus and Scirpus maritimus var. maritimus. Farther upstream, in the oligohalinicum and the freshwater tidal zone, Scirpus lacustris ssp. lacustris and Scirpus triqueter join these taxa (ZoNNEveld, 1960).

\subsection{Plant communities on salt marshes and beach plains}

As the environment of salt marshes and beach plains is more stable than eu-littoral formations, the number of species is larger and also the spatial variability within the communities is wider. This involves that the boundaries between the communities become vaguer and more floristic affinity between the communities is observed. Except the tidal-drift communities, which will be discussed in the following section, the salt-marsh communities are classified into three alliances, viz. the Puccinellion maritimae, the Armerion maritimae and the Puccinellio maritimae-Spergularion salinae. These alliances are united into the order Glauceto-Puccinellietalia, for which Limonium vulgare ssp. pseudolimonium (Rchb.) Gams, Spergularia marginata, Plantago maritima, Triglochin maritima and Aster tripolium are characteristic.

The Puccinellion maritimae develops in the basins and on low creek banks of the salt marshes, in low places of beach plains, and in other saline localities, generally situated within the reach of spring tides. It occurs optimally in the eu-haline and polyhaline zones, but penetrates far into the mesohalinicum. The alliance is represented by two associations:

(1) Puccinellietum maritimae. Develops in the basins and other low places in different floristic and structural compositions, depending on salinity and soil-moisture fluctuations, as well as on the intensity of grazing. The most common association on the salt marshes, corresponding to the "General Salt Marsh (G.S.M.)", distinguished by English authors (e.g. Chapman, 1934, 1960; Tansley, 1949).

(2) Halimionetum portulacoidis. Exclusively on the more drained clayey soils of low creek banks and the slopes of larger ones, and in well-drained, non-grazed basins. Confined to the eu-haline and polyhaline zones. Once established Halimione portulacoides is able to endure sedimentation of sand very well.

The Armerion maritimae is found on the higher parts of the salt marshes and beach plains, generally above spring-tide level, and nearly exclusively within the eu-haline and polyhaline zones. In the SW Netherlands three associations have been recognized:

(1) Artemisietum maritimae. Exclusively on well-drained soils with a rather high salinity-level, such as the larger creek banks and abrasion edges.

(2) Juncetum gerardii. Communities with mostly domination of Juncus gerardii or Festuca rubra f. litoralis on sandy or superficially clayey 
soils between spring-tide level and storm-flood zone. In boundary situations between saline and fresh spheres of influence the association is replaced by communities of the alliances Agropyro-Rumicion crispi (Loto-Trifolion), Saginion maritimae or Angelicion litoralis, or intermingled with species characteristic for these communities.

(3) Zunceto-Caricetum extensae. Confined to humid habitats on beach plains, being influenced to a certain extent by fresh water. Consequently, elements of the Agropyro-Rumicion crispi are always present. The association is very rare in the SW Netherlands. It is especially found in the Frisian Islands.

The third alliance of the order Glauceto-Puccinellietalia, the Puccinellieto maritimae-Spergularion salinae, is characteristic for saline habitats, tread by cattle or man. As a result of treading the vegetation is usually thin and the soil surface firm, which situation makes the salinity and the moisture contents of the soil fluctuate to a considerable extent. The nitrogen level is rather high. In the Netherlands the alliance occurs with three associations: (1) Puccinellietum distantis, (2) Puccinellietum fasciculatae and (3) Puccinellietum retroflexae. It seems that all three of them develop optimally under mesohaline conditions, but that their habitats especially differ in magnitude of the fluctuations in salinity and soil moisture. In these respects the Puccinellietum fasciculatae requires larger fluctuations in salinity than the Puccinellietum distantis, while especially in the Puccinellietum retroflexae the ground-water fluctuates to a lesser extent. The associations are mainly distributed on saline soils on the landside of the dikes. On the salt marshes the Puccinellietum distantis is more common than the Puccinellietum fasciculatae; the latter reaches the northernmost limit of its area of distribution in the SW Netherlands. The Puccinellietum retroflexae is rarely found on beach plains.

\subsection{Plant communities on tidal drift}

As its main influence tidal drift superposes irregularity on the saltmarsh ecosystem. The pattern as well as the composition of tidal depositions differ every year and so does its vegetation. Moreover, the magnitude of tidal drift varies largely in time and space. Thus, in the same way as is the case in other instable situations, mixtures of the original vegetation with species connected to this instability often occur. The classification of tidal-drift communities according to floristic composition coincides with differences in the kind of tidal drift, in the character of the receiving vegetation and in the salinity and humidity of the habitat (cf. section 5.5). The communities are placed in the classes Cakiletea maritimae and Artemisietea vulgaris. The first class is represented by the alliances Thero-Suaedion, Atriplicion littoralis and Salsolo-Honckenyon peploidis. Of the second class only the alliance Angelicion litoralis is relevant in this respect.

The Thero-Suaedion occurs in the SW Netherlands only with the Suaedetum maritimae. This association is confined to tidal drift, consisting 
of readily decomposing algae, and washed ashore on saline and humid places in the transition zone between mud flats and salt marshes. Optimally developed it is very poor in species.

The Atriplicion littoralis grows on tidal drift, mainly consisting of rests of phanerogams, and deposited on clayey soils in the storm-flood zone. In the eu-haline and polyhaline zones Atriplex species are aspect forming (Atriplicetum littoralis). In mesohaline and oligohaline zones, however, Cirsium arvense gradually dominates. The latter communities are classified into the Atripliceto-Cirsietum arvensis, belonging to the alliance Angelicion litoralis.

The third alliance of the Cakiletea maritimae, the Salsolo-Honckenyon peploidis, develops on tidal drift, washed ashore on beaches of sand and shingle, and covered more or less by wind-blown sand. Honckenya peploides, Cakile maritima and Salsola kali are characteristic for these communities.

When tidal drift is thrown in brushwood of whatever dimensions (e.g. Artemisia maritima, Hippophae rhamnoides) or in belts of erect grasses (Phragmites communis), communities of the alliance Angelicion litoralis develop, forming veils of vertical orientated plants in the original vegetation and sometimes superseding them. They grow optimally in the mesohaline environments of estuaries and beach plains. Elytrigia pungens seems to be the principal faithful species. Other characteristic species are Atriplex hastata, Cirsium arvense, Apium graveolens (AtriplicetoCirsietum arvensis), Althaea officinalis, Calystegia sepium, Cochlearia officinalis, Angelica archangelica ssp. litoralis (Fries) Thellung (Althaeeto-Calystegietum sepii) and Sonchus arvensis. In the polyhaline zone related communities occur, fairly rich in halophytes (Atripliceto-Elytrigietum pungentis).

\section{Epilogue}

The conception of fundamental antithesis between variety-in-space and variety-in-time, put forward by VAN LEEUWEN (1963), appears to be very useful to gain a deeper insight into the nature of maritime ecosystems. From this point of view it becomes obvious once more that the vegetation in its structure and development reflects the equality and inequality in space and time of the environment. So, the nature of organizations of organisms and that of the organisms themselves are closely bound up with both stability and instability in environmental processes. Besides, it becomes more clear that the nature of this stability and instability depends closely on the levels of environmental properties. These levels have especially been the object in the more classical approach in ecology.

In this way it seems to be that this presupposition of coincidence between vegetation and its habitat refers back to a more fundamental one, inherent to life: The paradoxal unity of the category of causality, being of an establishing - and thus objective - nature to the human mind, and of the category of functionalism, being regulative and thus subjective (LOEN, 1963). 


\section{SUMMARY}

This paper contains a survey of ecological and phytocoenological investigations on maritime vegetation, carried out in the SW Netherlands. After an outline of the nature of the Dutch coasts and of former investigations on salt-marsh vegetation, special attention is devoted to a cybernetic approach to this vegetation and its habitat as realizations in space and time. From an ecological point of view stability and instability in the environment appears to be of essential importance. Starting from this approach estuarine phenomena, the genesis of salt marshes and different physical and chemical properties of the soil (texture, carbonate contents, soil-water relations, salinity and supply of organic matter) are discussed, as well as their connections with some features of the vegetation. Using the same strain of thought, a survey of the vegetation is given, at the same time starting from the principles of classification according to the French-Swiss School of Braun-Blanquet.

\section{ACKNOWLEDGEMENT}

The author is much indebted to Dr. K. F. Vaas (Yerseke) for his valuable advices in formulating the text in English.

\section{REFERENCES}

Adriani, M. J. 1945. Sur la phytosociologie, la synécologie et le bilan d'eau de halophytes. Groningen, J. B. Wolters, $22+217 \mathrm{pp}$.

BAKKer, D. 1950. De vegetatie van de toekomstige Zuid-Sloeporder. Ned. Kruidk. Arch. 57: 135-137.

BAkker, D. and A. C. Bokr. 1957. De vegetatie van de Braakman in 1952. Van Zee tot Land 19: 1-15.

Barkman, J. J., H. Doing Kraft, Chr. G. van Leeuwen and V. Westhoff. 1958. Enige opmerkingen over de terminologie in de vegetatiekunde. Corr. blad Floristiek en Veg. onderz. Ned. 8: 87-93.

BeEftink, W. G. 1957. De buitendijkse terreinen van de Westerschelde en de Zeeschelde. Natuurwetenschappelijke betekenis, bedreiging door het Deltaplan en behoud voor de toekomst. Natuur en Landschap 11 : 33-51.

1962. Conspectus of the phanerogamic salt plant communities in the Netherlands. Biol. Jaarboek Dodonaea 30: 325-362.

1964. Polygonum maritimum $L$. in Nederland. With a summary in English. Gorteria 2: 13-20.

1965. De zoutvegetatie van ZW-Nederland beschouwd in Europees verband. Meded. Landbouwhogeschool Wageningen 65(1): 1-167.

Bendegom, L. van. 1950. Enkele beschouwingen over de vorming en vervorming van wadden. Tijdschr. Kon. Ned. Aardr. Gen. 67: 326-333.

Blaut, J. M. 1960. The nature and effects of shifting agriculture. Symposium on the impact of man on humid tropics vegetation, p. 185- 198.

Braun-Blanquet, J. 1928, 1951. Pflanzensoziologie. Grundzüge der Vegetationskunde. 1. Aufl. Berlin, Springer, $10+330$ pp.; 2. Auf. Wien, Springer, $11+631$ pp.

1932. Plant Sociology. Fnglish translation of "Pflanzensoziologie", first impression, 1928, by George D. Fuller and Henry S. Conard. New York, McGraw-Hill, 439 pp.

and W. C. DE LeEuw. 1936. Vegetationsskizze von Ameland. Ned. Kruidk. Arch. 46: 359-393.

Brouwer, G. A. et al. 1950. Griend, het vogeleiland in de Waddenzee, historischgeographisch, hydrographisch en biologisch beschreven. 's-Gravenhage, M. Nijhoff, $20+288 \mathrm{pp}$.

Chapman, V. J. 1934. The ecology of Scolt Head Island, p. 77-145. In: J. A. Steers, ed. Scolt Head Island. The story of its origin: the plant and animal life of the dunes and marshes. Cambridge, Heffer and Sons, 16+234 pp. 
1938. Studies in salt marsh ecology I-III. Jour. Ecol. $26: 144-179$. 1960. Salt marshes and salt deserts of the world. London, Leonard Hill, $16+392 \mathrm{pp}$.

Dahlbeck, N. 1945. Strandwiesen am südöstlichen Öresund. Acta Phytogeogr. Suecica 18: 1-168.

Du RIETz, G. F. 1930. Vegetationsforschung auf soziationsanalytischer Grundlage. In: Abdei halden: Handb. biol. Arbeitsmethoden 11 (5): 293-480.

Feeres, W. 1934. Schorrenstudie langs de Zuiderzee. Corr. blad Zuiderzee Onderz. 3: 91-122.

1941. De buitenlanden langs Oost- en Westkust van de Zuiderzee, voor en na de afsluiting. Ned. Kruidk. Arch. 51: 63-67.

Final Resolution of the Symposion on the classification of brackish waters. 1959. Arch. Océan. Limnol. 11 (suppl.): 243-245.

Fokkens, B. and J. C. DE Koning. 1960. Drainage in the Zuiderzee-reclamations. Fourth Congr. Intern. Comm. on Irrigation and Drainage, Madrid, Part I, R4: 11.49-11.63.

Grlfham, M. E. 1957. Vegetation of the Exe Estuary in relation to water salinity. Jour. Ecol. 45: 735-756.

GriethuYsen, G. van. 1964. Zomerkamp Axel, p. 75-95. In: H. Hillebrand, ed., Jaarboek C. J. N. 1964, mimeographed.

HARMSEN, G. W. 1936. Systematische Beobachtungen der nordwest-europaeischen Seegrasformen. Ned. Kruidk. Arch. 46: 852-877.

Hartog, G. DEN. 1958. De vegetatie van het Balgzand en de oeverterreinen van het Balgkanaal. Wetensch. Meded. K.N.N.V. 27: 1-28.

1959. The epilithic algal communities occurring along the coast of the Netherlands. Wentia 1 : 1-241.

1961. Die faunistische Gliederung im südwestniederländischen Deltagebiet. Int. Revue ges. Hydrobiol. 46: 407-418.

Kinzer, W. 1926. Neue Tabellen zu Frost und Licht als beeinflussende Kräfte bei der Samenkeimung. Stuttgart, E. Ulmer, $80 \mathrm{pp}$.

Korringa, P. 1941. Experiments and observations on swarming, pelagic life and setting in the european flat oyster, Ostrea edulis L. Arch. Néerl. Zool. 5: $1-249$.

LAMbert, J. M. 1964. The Spartina story. Nature 204: 1136-1138.

LANGENDONCK, H. J. VAN. 1931. De vegetatie en oecologie der schorrenplanten van Saaftingen. Bot. Jaarb. Dodonaea 23: 1-128.

1933a. Floristische en phytosociologische aantekeningen. Natuurwet. Tijdschr. 15: 39-44.

1933b. La sociologie végétale des schorres du Zwyn et de Philippine. Bull. Soc. Roy. Bot. Belgique 65 (2): 112-136.

Leeuwen, Chr. G. van. 1960. Beplantingen in het Nederlandse landschap. Vakbl. Biol. 40: 181-191.

1962. De hoogvenen van Twente. In: Twente-natuurhistorisch. III. Heiden, venen en vennen. Wetensch. Meded. K.N.N.V. 43: 21-38.

1963. The open-and-closed theory as a possible contribution to cybernetics. Mimeographed summary of a lecture at the Dutch section for information theory of the Intern. Significal Society, February 1963, and discussed at the 10th Intern. Bot. Congress, Symp. on Classification and Ordination of Vegetation, Edinburgh, August 1964.

1965. Het verband tussen natuurlijke en anthropogene landschapsvormen, bezien vanuit de betrekkingen in grensmilieu's. With a summary in English. Gorteria 2: 93-105.

Loen, A. E. 1963. Het vooronderstelde. Kentheoretische ontgrenzingen. 's-Gravenhage, Boekencentrum N.V., 87 pp.

MAarel, E. VAN DER; V. Westhoff and CHR. G. van Leeuwen. 1964. European approaches to the variation in vegetation, considered from a systemtheoretical point-of-view. Mimeographed paper, discussed at the 10th Intern. Bot. Congress, Symp. on Classification and Ordination of Vegetation, Edinburgh, August 1964.

Margalef, R. 1958. Information theory in ecology. Gen. Systems, Yearbook of the Soc. for Gen. Systems Res. 3: 36-73. 
1961. Communication of structure in planktonic populations. Limn. and Oceanogr. 6: 124-128.

Mörzer Bruijss, M. F. et al. 1953. Vegetatie-onderzoek van het Zwin in 19511952. Bull. Rijksplantentuin 23: 81-123.

MozLey, A. 1954. An introduction to molluscan ecology. Distribution and population studies of fresh water molluscs. Iondon, H. K. Lewis and Cy., $71 \mathrm{pp}$.

Pons, L. J. et al., 1963. Evolution of the Netherlands coastal area during the Holocene. Verh. Kon. Ned. Geol. Mijnbouwk. Gen. 21 (2): 197-208.

QuAstLer, H. 1959. Information theory of biological integration. Amer. Nat: 93 (871): 245-254.

Roosma, M. 1961. De halophiele vegetatie van het schor te Oostvoorne. Mimeographed, $36 \mathrm{pp}$.

Ross Ashry, W. 1961. An introduction to cybernetics. London, Chapman and Hall, $10+295^{\circ} \mathrm{pp}$.

Slopr, J. G. 1936. Planten langs de Schelde. Natura 35: 168-185.

SPEKmAN, J. and J. GroteN. 1963. Enkele aspecten van het Saginetum maritimae op de Beer en de Boschplaat. Mimeographed, 32 pp.

SrÄRGKE, A. 1944-45. Het kweken van wilde planten. In Weer en Wind 8: 102-105, 133-137 and 151-153.

StraAten, L. M. J. U. van. 1963. Aspects of holocene sedimentation in the Netherlands. Verh. Kon. Ned. Geol. Mijnbouwk. Gen. 21 (1): 149-172.

Tanslex, A. G. 1949. The British Islands and their vegetation. Cambridge, Univ. Press, $66+930$ pp.

Terwindt, J. H. J.; J. D. DE Jong, and E. van Der Wilk. 1963. Sediment movement and sediment properties in the tidal area of the lower Rhine (Rotterdam Waterway). Verh. Kon. Ned. Geol. Mijnbouwk. Gen. 21(2): 243-258.

Turis, T. G. 1936. New species of Zostera from Britain. Jour. Bot. 74: 227-230.

1942. Biological flora of the British Isles. Zostera L. Jour. Ecol. 30: 217-226.

TüxEN, R. 1950. Grundrisz einer Systematik der nitrophilen Unkrautgesellschaften in der Furosibirischen Region Europas. Mitteil. Flor.-soziol. Arbeitsgem. N. F. 2: 94-175.

1957. Die Pflanzengesellschaften des Auszendeichslandes von Neuwerk. Mitteil. Flor.-soziol. Arbeitsgem. N.F. 6/7: 205-234.

and V. Westhorp. 1963. Saginetea maritimae, eine Gesellschaftsgruppe im wechselhalinen Grenzbereich der europäischen Meeresküsten. Mitteil. Flor.-soziol. Arbeitsgem. N.F. 10: 116-129.

VERHOEVEN, B. 1963. On the calciumcarbonate content of young marine sediments. Bull. Intern. Inst. Land Reclamation and Improvement Wageningen 4: $1-27$.

Vlirger, J. 1938. Plantensociologische aanteekeningen in Oostelijk ZeeuwschVlaanderen. Ned. Kruidk. Arch. 48: 35-43.

VRIEs, D. M. DE. 1935. Plantengezelschappen als kenteeken van het keukenzoutgehalte van den bodem. Ned. Kruidk. Arch. 45: 97-121.

1940. De plantengroei van de aanslibbingen in het noorden van Nederland. In: W. Feekes; S. Scheygrond and D. M. de Vries. Botanische landschapsstudies in Nederland. Groningen, J. B. Wolters, 151 pp.

WeEvers, TH. 1940. De flora van Goeree en Overflakkee dynamisch beschouwd. Ned. Kruidk. Arch. 50: 285-354.

Westhofr, V. 1941. Systematik der Pflanzengesellschaften (Griend). Ned. Kruidk. Arch. 51 : 57-59.

- 1943. Plantensociologisch onderzoek, in het bijzonder van de Waddeneilanden. Hand. 29th Ned. Nat. en Geneesk. Congr., Amsterdam: 27-41. 1947. The vegetation of dunes and salt marshes on the Dutch Islands of Terschelling, Vlieland and Texel. 's-Gravenhage, G. J. van der Horst, $131 \mathrm{pp}$.

1951a. De Boschplaat op Terschelling. Natuur en Landschap 5: 3-20.

1951b. De Weidechampignon (Agaricus campestris Fr.) in en om de zilvermeeuwenkolonie van de Boschplaat op Terschelling. Fungus 21 :33-36. 
1954. Landschap en plantengroei van Schiermonnikoog. Natuur en Techniek 22: 1-10.

and W. G. BEEFTINK. 1950. De vegetatie van duinen, slikken en schorren op de Kaloot en in het Noord-Sloe. De Levende Natuur 53: 124-133 and 225-233.

and G. A. Brouwer. 1951. De natuurwetenschappelijke betekenis van het staatsnatuurmonument de Boschplaat op Terschelling. Amsterdam, Contactcomm. voor Natuur- en Landschapsbescherming, 40pp.

, Chr. G. van Leeuwen and M. J. Adriani. 1961. Enkele aspecten van vegetatie en bodem der duinen van Goeree, in het bijzonder de contactgordels tussen zout en zoet milieu. Jaarboek 1961 Wetensch. Gen. Goeree en Overflakkee: 1-127.

Zonneveld, I. S. 1960. De Brabantse Biesbosch. Een studie van bodem en vegetatie van een zoetwatergetijdendelta. With a summary in English. Wageningen, Pudoc, 210 pp. 